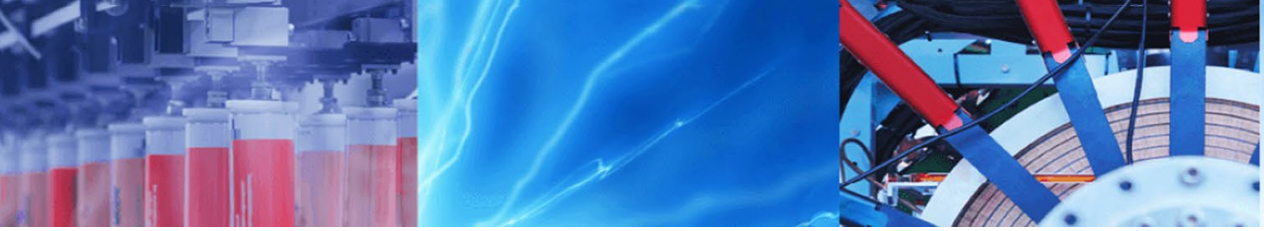

Research Article

\title{
Longshore sediment transport: predicting rates in dissipative sandy beaches at southern Brazil
}

\author{
Gabrielle Pereira Quadrado $^{1}$ (D) . Elaine Siqueira Goulart ${ }^{2}$ (D)
}

Received: 6 March 2020 / Accepted: 17 July 2020 / Published online: 25 July 2020

(c) Springer Nature Switzerland AG 2020

\begin{abstract}
Longshore sediment transport (LST) acts on beach morphodynamics on distinct temporal scales, being fundamental over sediment budget, and, so over the dynamic balance of coastlines. This study determined the most adequate methodology to estimate rates of non-cohesive sediments (from fine sand to gravel) transported by longshore currents, in the surf zone, under different meteoceanographic conditions, at the southern coast of Rio Grande do Sul (RS), Brazil. The methods proposed by CERC (Shore Protection Manual, Coastal Engineering Research Center (CERC), US Army Corps of Engineers Research and Development Center, Coastal and Hydraulics Laboratory, Vicksburg, 1984), Kamphuis (J Waterw Port Coast Ocean Eng 117(6):624-640, 1991), Bayram et al. (Coast Eng 54:700-710, 2007) and Van Rijn (Coast Eng 90:23-33, 2014) were tested through the comparison with data collected with streamer traps, as well as through statistical tests. Van Rijn (2014) was elected the most suitable approach for all beaches studied, followed by CERC (1984). The other two did not perform well for the study area. All models resulted in underestimated rates during high-energy scenarios, and this is attributed to wind negligence or insufficient weight factor in model's calculations, besides the lack of sampled data during very energetic conditions. Wave characteristics, median grain size and beach slope were proven to strongly influence LST, in accordance with the choice of best model overall. LST behavioural response and model's effectiveness will be different for each specific region, especially in what concerns the beach morphodynamic stage. Hence, the method prediction accuracy depends greatly on the suitability of the dataset with respect to the analytical model being used.
\end{abstract}

Keywords Sediment transport · Analytical model · Wave climate $\cdot$ Longshore current $\cdot$ Littoral drift

\section{Introduction}

Coastal zones represent interface areas between the continents and the oceans, where a significant part of the global population settles given their logistic, recreational and cultural potentials, and the availability of resources. Sandy beaches are coastal environments that vary in time and space accordingly to the depositional morphology and the hydrodynamic behaviour of the region in which they are located [1]. The gradients generated by hydrodynamic processes cause alterations in beach morphology at the same time as the acting hydrodynamic is altered accordingly to the changes induced by morphology. Given the dynamics of coastal processes, sediments are constantly being moved; therefore, they are one of the most important morphodynamic components of these beaches. Hence, the sediment budget of a system modulates the dynamic balance of the coastline in different spatial and temporal scales [2].

Longshore currents $(\mathrm{LC})$ are generated by the oblique incidence of waves on the coast and flow parallel to this interface, besides having potential to transport sediments

Gabrielle Pereira Quadrado, gabriellepquadrado@gmail.com | Programa de Pós-Graduação em Geociências (PPGGEO), Instituto de Geociências (IGEO) - Universidade Federal do Rio Grande do Sul - UFRGS, Av. Bento Gonçalves, Prédio 43113, Porto Alegre, RS 91501-970, Brazil. ${ }^{2}$ Laboratório de Oceanografia Geológica (LOG), Instituto de Oceanografia (IO) - Universidade Federal Do Rio Grande - FURG, Av. Itália, km 8, s/n, Bairro Carreiros, Rio Grande, RS 96203-000, Brazil. 
by suspended load or bedload, constituting, thus, the longshore sediment transport (LST) [3]. LST acts on beach morphodynamics in temporal scales from short to long term [4], playing a fundamental role on sediment budget, mainly in microtidal regions dominated by wave action [5]. The disturbance of this budget can be triggered by natural phenomena or by anthropic interference, and persistent LST gradients, even in low rates, can result in impacts like coastline retreat $[3,4]$.

The prediction of LST rates and its effects are the aim of many studies developed in oceanography and coastal engineering fields $[4,6-15]$. Yet, there is no consistent agreement of which is the best methodology to make predictions. Numerical modelling (process-based and analytical) is one of the most used methods when it comes to estimate LST rates, considering the limitations imposed by the adversities of measuring it in situ due to the surf zone hydrodynamics. Furthermore, numerical models represent a systematic comprehension of longshore transport once they allow the integration and the insertion of many parameters involved in this mechanism $[2,14]$.

Mixed beaches are composed of both sand and gravel fractions and are commonly distributed along the shorelines worldwide [16]. Given their complex dynamic associated with sorted grains of multiple sizes, the LST mechanism of mixed beaches is historically less investigated, and so, poorly understood when compared to the progress already made towards sandy beaches [16-21]. LST rates of beaches with coarser grain sizes and steeper slopes result from a different balance of morphodynamic processes than environments with fine sand; thus, classic formulae proposed, initially, for sandy beaches may not be suitable for mixed and shingle beaches [20]. In recent years, there is a growing interest concerning the establishment of reliable methods to predict LST rates in these beaches. New formulae have been proposed, and older analytical models have been revalidated and/or calibrated [4, 16, 20-23].

Hence, this study proposed the investigation and validation of the most applicable methodology to estimate the longshore transport of non-cohesive sediments at the southern shore of Rio Grande do Sul, Brazil, along varying grain size beaches. The potential of classic analytical models was evaluated like CERC [24] and Kamphuis [25], as well as two more recent alternatives developed by Bayram et al. [26] and Van Rijn [23]. All consist of analytical formulae considering process-based models in their creation and calibration processes. In this manner, the best alternative considering the study area was identified.

Mil-Homens et al. [4] and Van Rijn [23] also compared the efficiency of the models investigated herein [23-25], finding underestimated rates for energetic meteoceanographic conditions and overestimated values for low energy scenarios, for all the methods evaluated. When the parameters considered in the equation of each of these three models are compared, many similarities occur, specially between [23, 25]. Van Rijn [23] derives from an older formula proposed in Van Rijn [22], in which the new equation was obtained from a trial with CERC [24], Kamphuis [25] and a process-based model. The same parameters considered in [25] were maintained, because these studies found a good response of LST rates to profile shape/beach slope, significant wave height and median grain size. However, weight factors were modified and Van Rijn [23] also added low-period swell, wind and tide effects.

Overall, this research is a cooperation with previous studies, which also examined the LST mechanism in different regions around the world $[4,5,12-15,20,21,23]$, aiming the advancement of more accurate longshore transport assessing tools, thus contributing to the comprehension of short-term coastline evolution, the evaluation of sediment budgets for coastal areas and the long-term stability of beach protection measures [23].

\section{Physical settings}

The study was conducted at the southern shore of Rio Grande do Sul (RS), Brazil, considering the region located between Mar Grosso Beach, to the north of Patos Lagoon mouth in São José do Norte city, and Concheiros Beach, in Santa Vitória do Palmar city (Fig. 1). Field work made in this research was carried out in Cassino Beach, Rio Grande. The other field datasets in this study were obtained by Perotto [27] and Fontoura et al. [2] in the following places: Cassino beach, the roots of the jetties in Patos Lagoon, Mar Grosso beach, Sarita, Verga, Albardão, Concheiros and Concheiros Sul.

The southern shore of RS is approximately $220 \mathrm{~km}$ long, oriented by a NE-SW axis, with an almost straight coastline with subtle wavy stretches. It is characterized by a wide adjacent continental shelf, with a varying slope (smoother to the north, next to Cassino beach, and steeper to the south, close to Albardão and Concheiros).

Cassino is a dissipative beach, presenting intermediate stages with troughs, alongshore rhythmic bars and rip currents [28-31]. Concheiros Beach has reflective characteristics; thus, it is more susceptible to wave action and erosion [28]. The remaining beaches are under intermediate morphodynamic stages, displaying variations along the coast. The diversity is, partially, due to beach slope and the varying grain size distribution. The coast is predominantly composed of fine sand from Mar Grosso Beach until the north of Sarita lighthouse, influenced by Patos Lagoon discharge. The occurrence of thicker grain sizes, such as coarse sand and biodetritic gravel, is more common to the south of the study area, from Albardão lighthouse to 


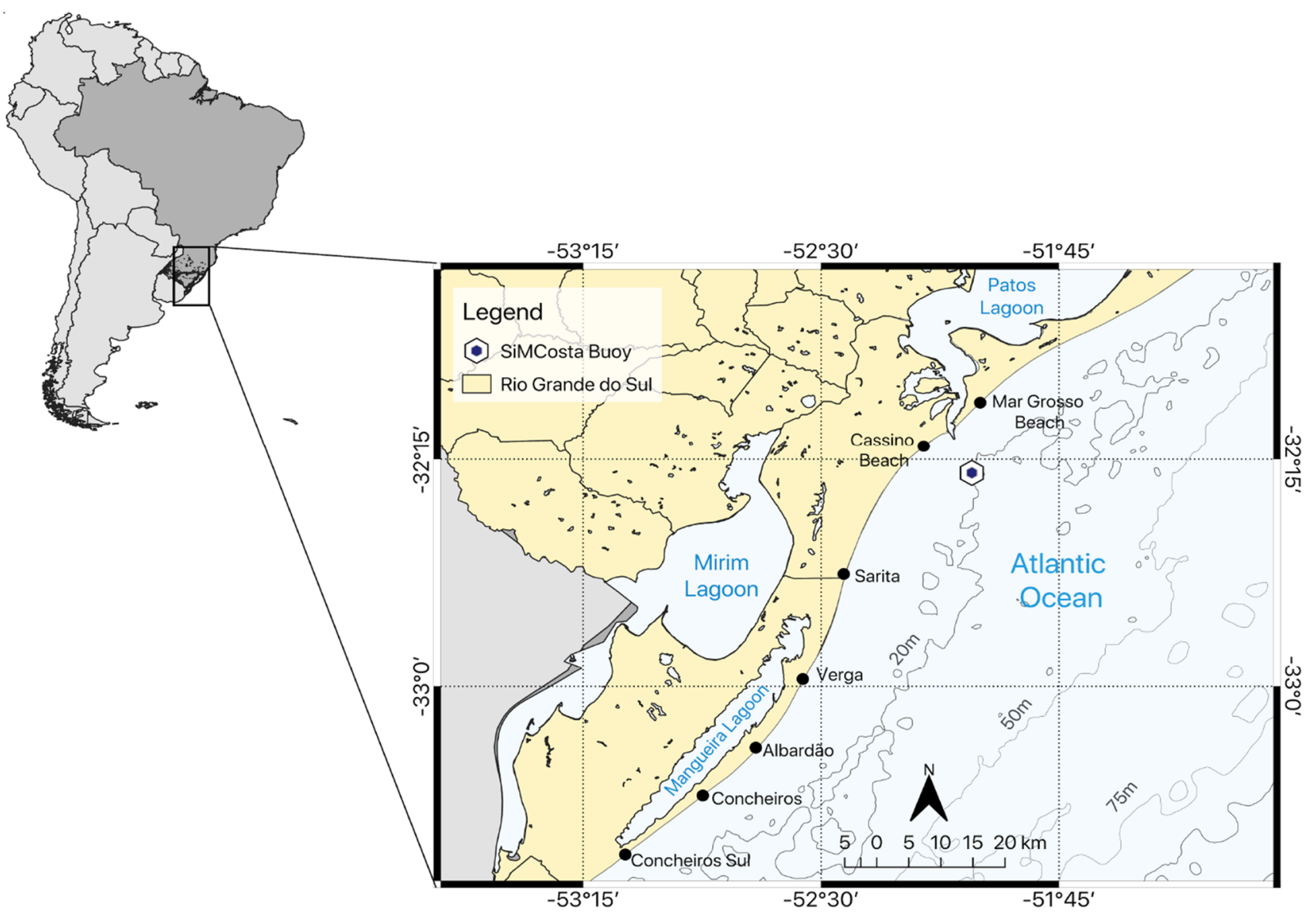

Fig. 1 Map of the study area, in which black dots represent the sampling sites of field surveys and the hexagon corresponds to the SiMCosta buoy

Concheiros Beach [28, 32]. Beach declivity increases from Mar Grosso $(\approx 0.018)$ towards Concheiros $(\approx 0.077)$. More details regarding grain size and beach slope data of each site under study are given in Table 1 of Sect. 3.3.

The astronomical tide follows a microtidal semidiurnal regime [36]. However, the meteorological tide can reach levels around $1.90 \mathrm{~m}$ during the occurrence of high-energy events [36, 37]. Two high-pressure systems of winds influence the RS coast: the South Atlantic anticyclone and the migratory polar anticyclones. The dominant wind throughout the whole year comes from NE, but the alternation among these two systems makes NE winds more frequent during spring and summer (September to February) and winds coming from the south quadrant more often through fall and winter (April to August), concomitantly with the incidence of frontal systems and the passage of storms $[36,38]$.

Wave climate is the most important hydrodynamic agent in this area, and it is characterized by three types of waves: swell, sea waves and storm waves [36]. Swell waves are originated mainly from SE by the tempestuous subpolar belt in the South Atlantic, sea waves usually propagate from NE, generated by the local winds, and storm waves are less frequent, but represent the most energetic ones. Littoral drift is bidirectional along the whole state, with a net transport towards NE associated with the intensification of littoral drift and LST during the passage of storms and highly energetic events [36-41].

\section{Material and methods}

\subsection{Field surveys}

Field surveys were similar for all the author's mentioned herein, with a few differences regarding wind and wave data collection. The samples of non-cohesive sediments transported by longshore currents were collected with streamer traps developed by Kraus [9], installed in the surf zone. The trap is a metallic structure, $1.80 \mathrm{~m}$ high, and it displays a set of 10 capture nets (nylon, $63 \mu \mathrm{m}$ mesh). The nets are numbered from 1 to 10 , bottom to top, and 
Table 1 Values of physical-chemical parameters and beach morphology data used in the analytical models

\begin{tabular}{|c|c|c|c|}
\hline Parameter & Symbol & Value & References \\
\hline Porosity & $\phi$ & 0.3739 & Author's measurement \\
\hline \multirow[t]{2}{*}{ Particle settling velocity } & \multirow[t]{2}{*}{$W_{\mathrm{s}}$} & $\begin{array}{l}0.0181 \mathrm{~m} \mathrm{~s}^{-1} \text { (EMA-Cassino) } \\
0.0210 \mathrm{~m} \mathrm{~s}^{-1} \text { (Mar Grosso) }\end{array}$ & Espírito Santo [33] \\
\hline & & $\begin{array}{l}0.0125 \mathrm{~m} \mathrm{~s}^{-1} \text { (Terminal/West Jetty-Cassino) } \\
0.0181 \mathrm{~m} \mathrm{~s}^{-1} \text { (Sarita) } \\
0.0181 \mathrm{~m} \mathrm{~s}^{-1} \text { (Verga) } \\
0.0204 \mathrm{~m} \mathrm{~s}^{-1} \text { (Albardão) } \\
0.0220 / 0.1500 \mathrm{~m} \mathrm{~s}^{-1} \text { (Concheiros/Concheiros Sul) }\end{array}$ & Calliari et al. [28] \\
\hline Gravity acceleration & $g$ & $9.80665 \mathrm{~m} \mathrm{~s}^{-2}$ & - \\
\hline Dimensionless coefficient & $K$ & 0.01 & $\begin{array}{l}\text { CERC [24] modified by } \\
\text { Fontoura et al. [2] }\end{array}$ \\
\hline Median grain size & $D_{50}$ & $\begin{array}{l}0.125 \mathrm{~mm} \text { (EMA_Cassino) } \\
0.136 \mathrm{~mm} \text { (Terminal/West Jetty_Cassino) } \\
0.144 \mathrm{~mm} \text { (Mar Grosso) } \\
0.177 \mathrm{~mm} \text { (Sarita) } \\
0.177 \mathrm{~mm} \text { (Verga) } \\
0.192 \mathrm{~mm} \text { (Albardão) } \\
0.210 / 0.707 \mathrm{~mm} \text { (Concheiros/Concheiros Sul) }{ }^{\mathrm{a}}\end{array}$ & Calliari et al. [28] \\
\hline \multirow[t]{2}{*}{ Beach slope } & \multirow[t]{2}{*}{$\tan \beta$} & $\begin{array}{l}0.022 \text { (EMA—Cassino) } \\
0.020 \text { (Terminal-Cassino) } \\
0.0185 \text { (West Jetty-Cassino) } \\
0.0180 \text { (Mar Grosso-East Jetty) } \\
0.0140 \text { (Mar Grosso-3 km) } \\
0.0225 \text { (Mar Grosso-12 km) }\end{array}$ & $\begin{array}{l}\text { Author's measurement } \\
\text { Fontoura et al. [2] }\end{array}$ \\
\hline & & $\begin{array}{l}0.056 \text { (Sarita) } \\
0.043 \text { (Verga) } \\
0.053 \text { (Albardão) } \\
0.077 \text { (Concheiros/Concheiros Sul) }\end{array}$ & Calliari et al. [28] \\
\hline Sediment density & $\rho_{\mathrm{S}}$ & $2650 \mathrm{~kg} \mathrm{~m}^{-3}$ & $\begin{array}{l}\text { Martins [34] } \\
\text { Bessler and Rodrigues [35] }\end{array}$ \\
\hline Seawater density & $\rho_{\mathrm{H} 2 \mathrm{O}}$ & $1025 \mathrm{~kg} \mathrm{~m}^{-3}$ & Author's measurement \\
\hline $\begin{array}{l}\text { Wind-induced longshore current } \\
\text { velocity }\end{array}$ & $V_{\text {LC WIND }}$ & $0.10 \mathrm{~m} \mathrm{~s}^{-1}$ & Van Rijn [23] \\
\hline Swell factor & $K_{\text {swell }}$ & $\begin{array}{l}1.0 \text { for } T_{\mathrm{p}}<9 \mathrm{~s}, H_{\mathrm{s}}<0.7 \mathrm{~m} \text { (absent swell) } \\
1.5 \text { for } T_{\mathrm{p}} \geq 9 \mathrm{~s}, H_{\mathrm{s}} \geq 0.7 \mathrm{~m}(\text { swell) })^{\mathrm{b}}\end{array}$ & Van Rijn [23] \\
\hline
\end{tabular}

${ }^{a}$ Concheiros presents a bimodal sediment distribution, in which fine sand is represented by $D_{50}=0.2102 \mathrm{~mm}$ and $W_{\mathrm{s}}=0.0220 \mathrm{~m} \mathrm{~s}{ }^{-1}$, and the biodetritic gravel is denoted by $D_{50}=0.707 \mathrm{~mm}$ and $W_{\mathrm{s}}=0.1500 \mathrm{~m} \mathrm{~s}^{-1}$

${ }^{\mathrm{b}} K_{\text {swell }}$ is based on the percentage of low-period swell wave heights of the total wave height record $=p_{\text {swell }}$. Considering wave data used herein regards the exact period in which in situ surveys were conducted, $p_{\text {swell }}=100 \%$

have different lengths: 1 to $6=60 \mathrm{~cm}, 7$ to $8=70 \mathrm{~cm}$ and 9 to $10=110 \mathrm{~cm}$. The size variation aims to optimize operational efficiency according to considerations made in $[2,9]$.

Samples were collected during a 3-5-min interval, since after this period bottom flow is altered due to the presence of the trap, misrepresenting, thus, its natural dynamic. In each field survey, two to four sampling stations were set in the same transverse profile. LST rates, represented by $Q_{T}$, are estimated according to a set of equations proposed by Wang [42] as described by Eqs. 1, 2 and 3 , where $\Delta F_{I}=$ sediment flux between two adjacent nets $\left(\mathrm{kg} \mathrm{s}^{-1}\right) ; F_{l+1}$ and $F_{l-1}=$ fluxes through the upper and lower nets $\left(\mathrm{kg} \mathrm{s}^{-1}\right)$, respectively; $Z_{I+1}$ and $Z_{I-1}=$ vertical width of the opening of the upper and lower nets (m), respectively; $\Delta Z_{1}=$ distance between two adjacent nets $(\mathrm{m}) ; I=$ total flux passing through all capture nets $\left(\mathrm{kg} \mathrm{h}^{-1} \mathrm{~m}^{-2}\right) ; n=$ number of nets mounted on the trap $=10 ; i=$ identifier number of each streamer trap on the surf zone; $I_{i}=$ sediment flux measured at trap array $i$ $\left(\mathrm{kg} \mathrm{h}^{-1} \mathrm{~m}^{-2}\right)$; and $A_{i}=$ surf cross-sectional area between traps $i$ and $i+1\left(\mathrm{~m}^{2}\right)$. 
$\Delta F_{I}=\left(\frac{\frac{F_{l+1}}{Z_{l+1}}+\frac{F_{l-1}}{Z_{l-1}}}{2}\right) \Delta Z_{I}$

$I=\sum_{i=1}^{n} F_{l}+\sum_{1=1}^{n-1} \Delta F_{l}$

$Q_{\mathrm{T}}=\sum \frac{I_{i}+I_{i+1}}{2} A_{i}$

The field work followed a standard procedure: (1) beach profile-profiles were taken using a Nikon Nivo $2 \mathrm{C}$ total station and a surveying reflection prism. Profiles were used to identify the location of sampling stations, bathymetric features, mean waterline position (mean swash zone position), breaker point depth $h b$ (defined as the vertical distance between the seabed and the waterline in the breaking point) and beach slope, represented by the tangent of the beach inclination angle $\tan \beta$; $(2)$ wind measurement-wind velocity and direction were measured with an anemometer, a windsock and a compass; (3) longshore current-currents were measured with a drifting buoy, made with PET bottles containing sand, a chronometer and marking stakes (Lagrangian measurement). Velocity is measured as a function of the time that the drifter takes to travel $30 \mathrm{~m}$ in the surf zone. This procedure is triplicated, and an average of the three values obtained is made. (4) Last is the longshore sediment transport step, in which streamer traps are used to sample sediments under longshore transport.

Sediment samples were washed with fresh water to remove the salts, dried in a stove $\left(80-100^{\circ} \mathrm{C}\right)$, and then, the grain size analysis was performed with a precision scale and a set of stainless steel sieves (interval $1 / 4 \varphi$ in the Wentworth [31] scale).

\subsection{Wave data}

Authorial wave data were provided by the Sistema de Monitoramento da Costa Brasileira (SiMCosta), collected with a directional waverider buoy moored adjacent to Cassino beach ( $\left.32^{\circ} 17^{\prime} 43.03^{\prime \prime} \mathrm{S} 52^{\circ} 1^{\prime} 29.95^{\prime \prime} \mathrm{W}\right), 17 \mathrm{~km}$ apart from the coastline. Perotto [27] and Fontoura et al. [2] measured wave parameters in the breakpoint through continuous filming of wave fields with posterior laboratory analysis. All wave data were converted from its initial acquisition form to a pattern considering the transformative processes associated with wave propagation in shallower waters. The conversion was made through linear regression, using significant wave height $H_{\mathrm{S}}$ (in meters), peak wave period $T_{\mathrm{p}}$ (in seconds) and wave propagation direction $D_{\mathrm{P}}$ (in degrees) simulated in the Simulating
WAves Nearshore (SWAN) model by [30], for the isobaths of $2.5 \mathrm{~m}$ and $19 \mathrm{~m}$. In order to obtain greater data accuracy, all of the converted wave components referred to a $4 \mathrm{~h}$ interval regarding the time in which field surveys were carried out. The surf zone width $L_{S z}$ was also estimated through linear regression using data from images obtained with the Argus video-imaging system $[43,44]$. The regression was made among the $L_{\mathrm{SZ}}$ measured through Argus images, $H_{\mathrm{S}}$ and $T_{\mathrm{P}}$ [45]. The correlation coefficients were $r=0.95$, $r=0.98, r=0.96$ and $r=0.39$, respectively, for $H_{\mathrm{S}}, T_{\mathrm{p}} D_{\mathrm{p}}$ and $L_{s Z}$ (Fig. 2). Although the $L_{s Z}$ coefficient seems low, it is significant for a $95 \%$ confidence interval with a significance level of 0.05 .

\subsection{LST rates}

The LST rates were estimated using 4 analytical models. The model described by CERC [24] presents an equation based on the principle that LST rates are proportional to the longshore component of wave energy (Eq. 4). The LST rate $Q_{L}$ corresponds to the immerse volume in $\mathrm{m}^{3} \mathrm{~s}^{-1}$, and it considers a dimensionless coefficient $K$-determined initially through linear regression using field data collected by Komar and Inman [8], researched later by other authors $[4,17,18,46-50]$ : gravity acceleration $g\left(\mathrm{~m} \mathrm{~s}^{-2}\right)$, seawater density $\rho_{\mathrm{H} 2 \mathrm{O}}\left(\mathrm{kg} \mathrm{m}^{-3}\right)$, sediment particles density $\rho_{\mathrm{s}}$ $\left(\mathrm{kg} \mathrm{m}^{-3}\right)$, porosity $\phi$ (dimensionless), $H_{\mathrm{S}}(\mathrm{m})$, breaker index $k$ (in accordance with the ratio between $H_{\mathrm{S}}$ and water depth) and $D_{\mathrm{p}}$ (degrees).

$$
Q_{\mathrm{L}}=\frac{K \cdot(\sqrt{g})}{(16 \cdot \sqrt{k}) \cdot\left(\rho_{\mathrm{S}}-\rho_{\mathrm{H}_{2} \mathrm{O}}\right) \cdot(1-\phi) \cdot\left(H_{\mathrm{S}}^{\frac{5}{2}}\right) \cdot\left(\sin 2 \cdot D_{\mathrm{P}}\right)}
$$

The model proposed by Kamphuis [25] allows to estimate LST rates $Q_{L}$ as a function of wave parameters, fluid and sedimentary characteristics, and beach profiles (Eq. 5). It has similarities with Eq. 4 (i.e. dimensionless coefficient $\left.K, \rho_{\mathrm{H} 2 \mathrm{O}}, g, H_{\mathrm{S}}, D_{\mathrm{P}}\right)$; however, it calculates the rates in $\mathrm{kg} \mathrm{s}^{-1}$ and includes $T_{\mathrm{p}}(\mathrm{s})$, beach slope $\tan \beta$ (dimensionless) and median grain size $D_{50}(\mathrm{~m})$.

$Q_{\mathrm{L}}=K \rho_{\mathrm{H}_{2} \mathrm{O}}\left(\frac{g}{2 \pi}\right)^{1.25} H_{\mathrm{S}}^{2} T_{\mathrm{P}}^{1.5} \tan \beta^{0.75} D_{50}^{-0.25} \sin \left(2 D_{\mathrm{P}}\right)^{0.6}$

Bayram et al. [26] define the $Q_{L}$ rate $\left(\mathrm{m}^{3} \mathrm{~s}^{-1}\right)$ as a product of the sediment concentration in suspension and the acting longshore current (Eq. 6). This method differs from the others mentioned before especially because it considers the mean longshore current velocity $V_{\mathrm{LC}}\left(\mathrm{m} \mathrm{s}^{-1}\right)$ in the surf zone. It is important to notice that the influence of waves, winds and tides is included in this parameter, because the total velocity is considered, not exclusively the parcel generated by the wave-induced longshore flux. Besides 

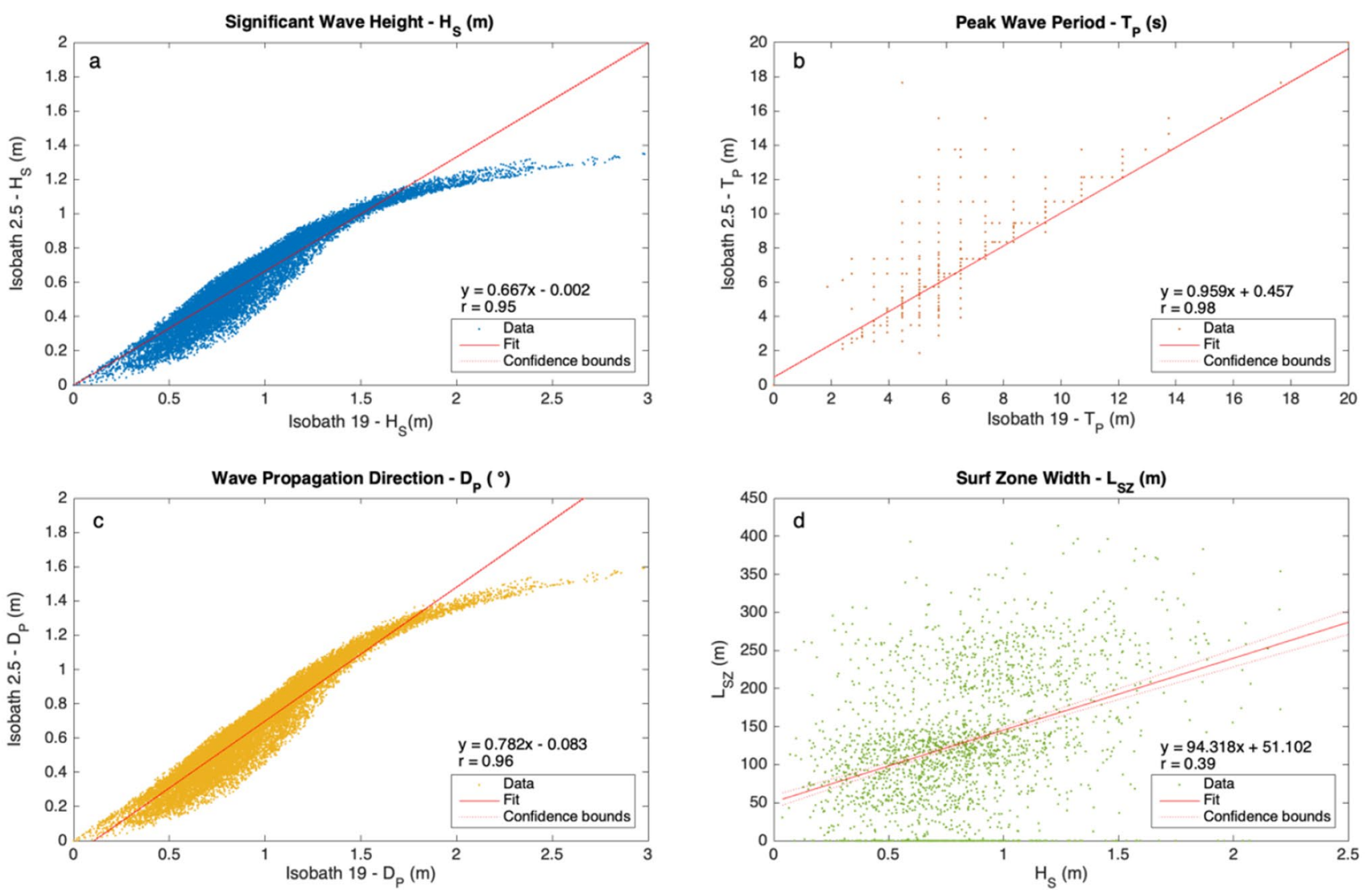

Fig. 2 Linear regression graphs referring to the relation between 19- and 2.5-m isobaths for $H_{\mathrm{S}}, T_{\mathrm{P}}$ and $D_{\mathrm{P}}(\mathbf{a}-\mathbf{c})$, and to the relation between $L_{\mathrm{SZ}}$ and $H_{\mathrm{S}}(\mathbf{d})$

that, this method assumes that suspension load is the dominant transport mechanism in the surf zone because the sediment deposited on the bottom is suspended by the continuous action of waves. Hence, this model suggests a transport coefficient $\varepsilon$ proportional to wave efficiency in keeping grains in suspension calculated through Eq. 7, considering the particle settling velocity $W_{\mathrm{S}}\left(\mathrm{m} \mathrm{s}^{-1}\right)$ instead of $D_{50}$. The wave-energy flux energy $F$ (Eq. 8) is also considered:

$Q_{\mathrm{L}}=\frac{\varepsilon}{\left(\rho_{\mathrm{S}}-\rho_{\mathrm{H}_{2} \mathrm{O}}\right) \cdot(1-\phi) \cdot g \cdot W_{\mathrm{S}}} \cdot F \overline{V_{\mathrm{LC}}}$

$\varepsilon=\left(9+4 \cdot \frac{H_{\mathrm{S}}}{W_{\mathrm{S}} \cdot T_{\mathrm{P}}}\right) \cdot 10^{-5}$

$F=E \cdot C_{G} \cdot \cos D_{\mathrm{P}}$

where $E=$ wave energy $\left(\mathrm{J} \mathrm{m}^{-2}\right)$ and $C_{\mathrm{G}}=$ wave group velocity in shallow waters $\left(\mathrm{m} \mathrm{s}^{-1}\right)$.

Van Rijn [23] proposes to estimate the $Q_{\mathrm{L}}$ rate in $\mathrm{kg} \mathrm{s}^{-1}$ using a simple general equation (Eq. 9). This method is derived from a previous trial [43] with a detailed process-based model, and in this more recent version, it is calibrated and revalidated, making $Q_{L}$ a function of a mobility coefficient $M$ obtained through Eq. 10:

$Q_{L}=0.0006 . M$

$M=K_{\text {swell }} \cdot \rho_{\mathrm{s}} \cdot(\tan \beta)^{0.4} \cdot\left(D_{50}\right)^{-0.6} \cdot\left(H_{\mathrm{S}}\right)^{2.6} \cdot V_{\mathrm{LC}}$ total

$V_{\mathrm{LC} \text { total }}=V_{\mathrm{LC} \text { wave }}+V_{\mathrm{LC} \text { wind }}$

$V_{\mathrm{LC} \text { wave }}=0.3 \cdot\left(g H_{\mathrm{S}}\right)^{0.5} \cdot \sin \left(2 D_{\mathrm{P}}\right)$

$V_{\mathrm{LC} \text { wind }}=0.01 \cdot p_{1} \cdot v_{1}+0.01 \cdot p_{2} \cdot v_{2}$

The mobility coefficient $M$ includes beach profile effects through beach slope, represented by $\tan \beta$, and through median grain size $D_{50}$, aiming a wider applicability of this method when it comes to different morphodynamic stages. It also contemplates the effect of low-period swell waves $\left(T_{p}=9-12 \mathrm{~s}, H_{\mathrm{s}}=0.70-2.0 \mathrm{~m}\right)$, indirectly considering $T_{p}$, since these waves can produce 
significantly larger transport rates when compared to wind waves of the same height [23].

The main equation (Eq. 10) considers the mean longshore current velocity $V_{\mathrm{LC} \text { total }}$ in $\mathrm{m} \mathrm{s}^{-1}$, just like the analytical model proposed by Bayram et al. [26]. However, it allows to distinguish the velocities induced by the waves $V_{\mathrm{LC} \text { wave }}$ from the tide-wind-induced velocities (Eqs. 11, 12, 13). The study area is under a microtidal regime; therefore, only the wind was considered as a influence factor over the LST, and so the tide-wind-induced velocity is represented by $V_{\mathrm{LC} \text { wind }}$ (Eq. 13), in which $p_{1}=$ percentage of time with positive flow; $p_{2}=$ percentage of time with negative flow; $v_{1}=$ representative velocity in positive longshore direction due to wind $\left(\mathrm{m} \mathrm{s}^{-1}\right) ; v_{2}=$ representative velocity in negative longshore direction due to wind $\left(\mathrm{m} \mathrm{s}^{-1}\right) \cdot V_{\mathrm{LC} \text { WIND }}=0.1 \mathrm{~m} \mathrm{~s}^{-1}$ as suggested by Van Rijn [23] for microtidal conditions.

LST rates estimation requires the awareness of many specific characteristics of the study area. Table 1 contains the values attributed to each parameter considered in the four models described above, except for the values referent specifically to the day of field surveys (i.e. waves, winds and longshore currents). It also displays information regarding data origin.

\subsection{Performance verification}

Analytical models were verified through different statistical methods as follows: (1) Bias-This calculation considered the resampling method through Jackknife [51], a nonparametric technique that reduces the estimator variance; (2) Root Mean Square Error (RMSE) - since LST rates extend through several orders of magnitude, logarithmic values (base 10) were considered for this statistical measure as proposed in [4]. When RMSE $=1$, it means that the modelled values are approximately ten times bigger or smaller than the sampled ones. The remaining are (3) Scatter Index (SI); (4) Pearson Correlation; (5) Spearman's Rank Correlation; and (6) Student's $t$ Test.

\section{Results}

\subsection{Field surveys}

This research comprehended seventeen field surveys in distinct beach locations, among the years of 2002, 2003, 2004 and 2018, under different meteoceanographic conditions. The predicted and observed results $Q_{\text {in situ }}$ can be seen in Fig. 3. The comparison between $Q_{\text {in situ }}$ and the predicted results allows to observe that the method proposed by Kamphuis [25] tends to underestimate the LST occurring in the system, representing the most unrealistic rates, varying in one order of magnitude for most of the cases. Predictions according to the model proposed by Bayram et al. [26] also resulted in underestimated rates for most of the scenarios. When it comes to CERC [24] and Van Rijn [23], no tendencies of under- or overestimation were observed, except for high LST scenarios (20/02/2003, 05/09/2003, 12/12/2004-Sarita, 07/08/2018), in which the estimates were lower than the observed in situ.

\subsection{Wave and wind data}

The conversion of wave parameters resulted in significant changes in $H_{S}$ and $D_{P_{1}}$ but not in $T_{p}$, which was almost constant for all the scenarios. Waves reduced around $33.9 \%$ of their original height, and the direction changed approximately $21.9 \%$, also with a reduction trend from the angle found at the 19-m isobath. The final converted values are in Table 2.

Multiple linear regression was applied aiming to identify the meteoceanographic agents with more influence over longshore currents and LST rates. The statistical tests were reproduced using different combinations between wind and wave variables (Table 3). It is important to notice that some of the displayed regressions consider wind direction instead of velocity, as seen in others, because only the best multilinear responses are shown in this table. Waves have more influence over the LST, for all parameters: LC velocity $(r=0.73)$, LC direction $(r=0.96)$ and LST rate $(r=0.89)$. Wind is only statistically significant over LC velocity $(r=0.70)$ and direction $(r=0.74)$. Although waves are more influent, when wave and wind components are combined as predictor variables, at least $95 \%$ of the LST is explained statistically, for all components.

\subsection{Analytical modelling}

The statistical results (Table 4) demonstrated that the model proposed by Van Rijn [23] is the most applicable to estimate LST rates in the southern region of Brazil. Van Rijn [23] was the only method that showed good results for all verification tests applied, being statistically significant in confidence levels of $95 \%(a=0.05)$ and $99 \%(a=0.01)$, for both correlations (Pearson and Spearman). It is the only model in which t-test has enough evidence to support that the predicted rates correspond to the observed values, and it is also the model with the lowest SI and RMSE.

Although CERC [24] has a t value that rejects the hypothesis that the predicted rates are similar to the observed ones, the correlation coefficients $r$ and $r_{s}$ are significant for the confidence intervals of $95 \%(a=0.05)$ and $99 \%(a=0.01)$. Moreover, this model results showed the lowest bias and low values of SI and RMSE. In this way, CERC [24] was considered the second most adequate method for the estimation of longshore transport rates 

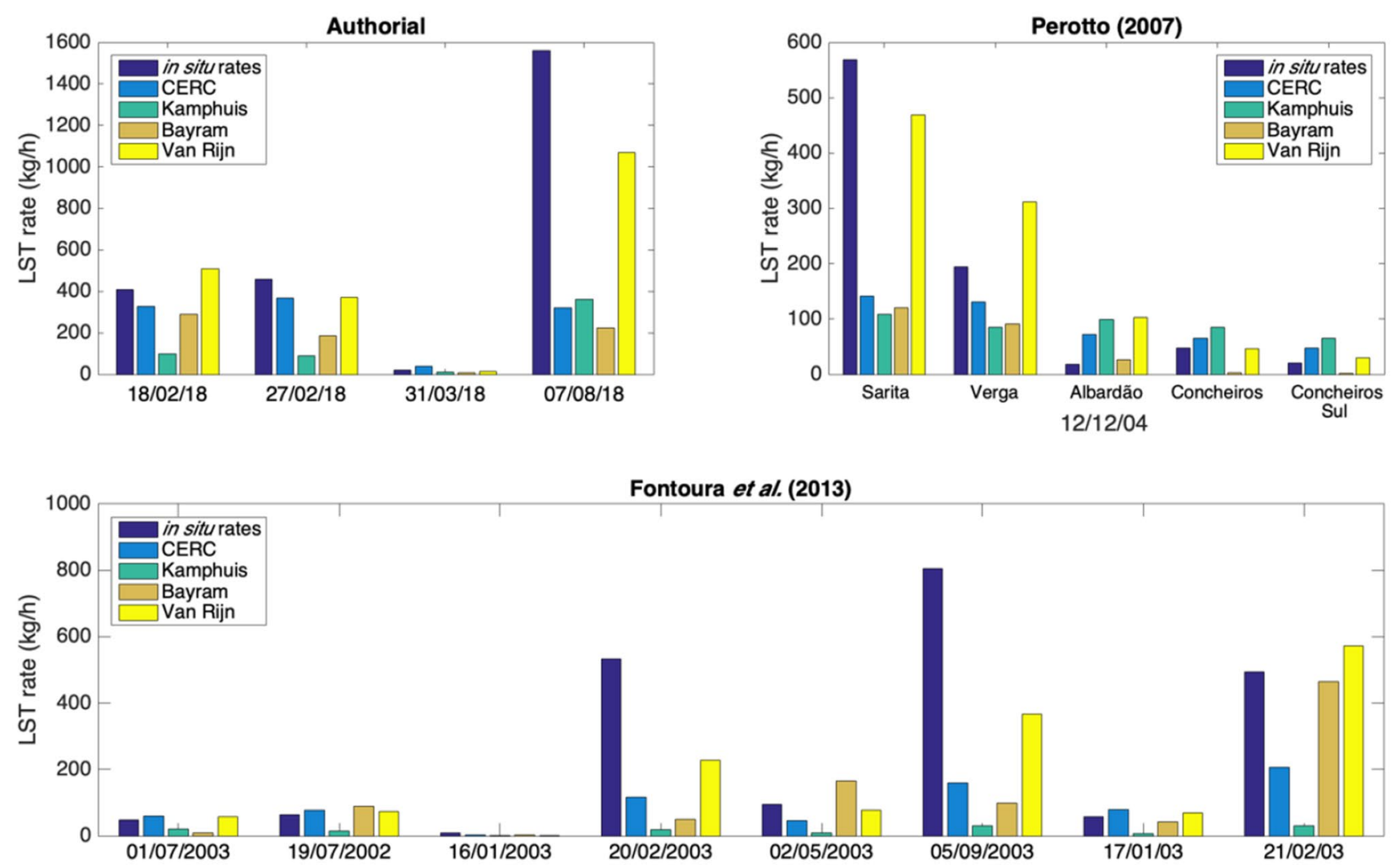

Fig. 3 Bars for LST rates comparing the predicted and observed data for each author. Notice that for Perotto [21], all field surveys occurred in the same date, and Fontoura et al. [2] rates are not arranged chronologically because they are disposed according to their sampling sites, as displayed in Table 2

set up, predominantly, by the characteristics of its generation wave, and the wind corroborates with the dynamics involved in the flux, influencing, hence, the amount of sediment mass being transported and in the resulting LST.

Beyond the statistics, the influence of winds was observed during the current author's field surveys: in 31 March 2018, the opposite incidence directions between the waves and the wind resulted in a low longshore sediment transport (forces were almost cancelling each other), and in 7 August 2018, the action of both components coming from the same quadrant resulted in an intensified LST rate, the highest value among all the period under investigation. In that way, it can be affirmed that the wind has potential to reduce or increase wave action over LC generation and, consequently, over LST, except when its intensity is too low or absent.

Besides being the most accurate model overall, Van Rijn [23] performed better for the authorial measurements than for the other datasets as seen in Fig. 3. It is supposed that the differences between wave data acquirement influenced the simulated rates. Thus, predictions were more accurate when wave parameters were sampled with SiMCosta buoy and later converted, rather 


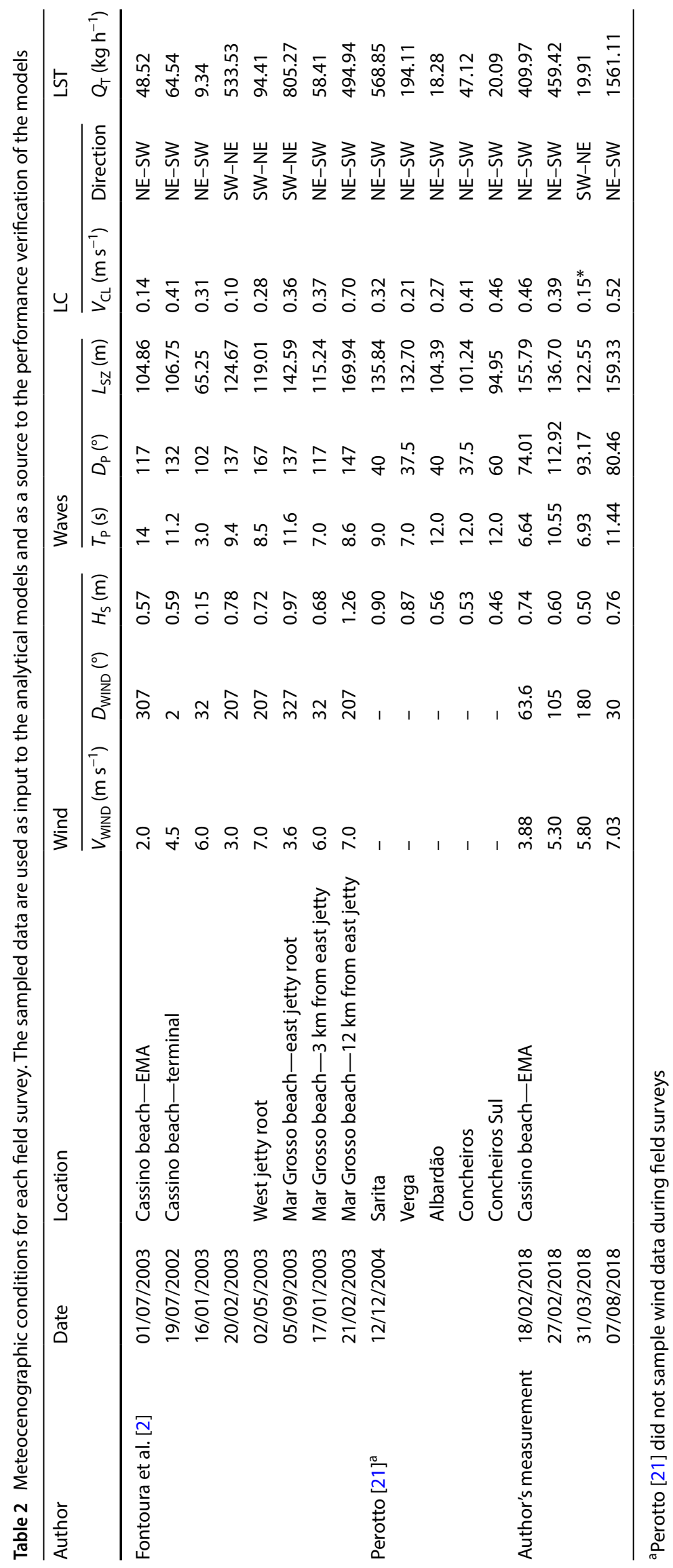


Table 3 Multiple linear regression coefficients relating $\mathrm{LC}$ velocity, $\mathrm{LC}$ direction and LST rates with wave and wind parameters

\begin{tabular}{|c|c|c|c|c|}
\hline Dependent variable & Predictor variable & $r$ & $R^{2}$ & Significance $\mathrm{Cl}=95 \%$ \\
\hline \multirow[t]{4}{*}{ Longshore current $-V_{\mathrm{LC}}\left(\mathrm{m} \mathrm{s}^{-1}\right)$} & Wave $-H_{\mathrm{S},} T_{\mathrm{P},} D_{\mathrm{P}}$ & 0.73 & 0.53 & Significant \\
\hline & Wind-velocity and direction & 0.70 & 0.49 & Significant \\
\hline & $\begin{array}{l}\text { Wave- } H_{\mathrm{S}}, T_{\mathrm{P}} \\
\text { Wind-velocity }\end{array}$ & 0.99 & 0.98 & Significant \\
\hline & $\begin{array}{l}\text { Wave- } H_{S}, D_{\mathrm{P}} \\
\text { Wind-velocity }\end{array}$ & 0.98 & 0.96 & Significant \\
\hline \multirow[t]{4}{*}{ Longshore current-direction $\left(^{\circ}\right)$} & Wave $-H_{\mathrm{S}}, T_{\mathrm{P}} D_{\mathrm{P}}$ & 0.84 & 0.71 & Significant \\
\hline & Wind-velocity and direction & 0.74 & 0.54 & Significant \\
\hline & $\begin{array}{l}\text { Wave- } H_{\mathrm{S}}, T_{\mathrm{P}} \\
\text { Wind-direction }\end{array}$ & 0.99 & 0.97 & Significant \\
\hline & $\begin{array}{l}\text { Wave- } H_{S}, D_{\mathrm{P}} \\
\text { Wind-velocity }\end{array}$ & 1.00 & 1.00 & Significant \\
\hline \multirow[t]{4}{*}{ LST rate $-Q_{T}\left(\mathrm{~kg} \mathrm{~h}^{-1}\right)$} & Wave $-H_{\mathrm{S}}, T_{\mathrm{P}} D_{\mathrm{P}}$ & 0.89 & 0.79 & Significant \\
\hline & Wind-velocity and direction & 0.40 & 0.16 & Not significant \\
\hline & $\begin{array}{l}\text { Wave- } H_{\mathrm{s}}, T_{\mathrm{P}} \\
\text { Wind-velocity }\end{array}$ & 0.96 & 0.93 & Significant \\
\hline & $\begin{array}{l}\text { Wave- } H_{\mathrm{s}}, D_{\mathrm{p}} \\
\text { Wind-velocity }\end{array}$ & 0.95 & 0.91 & Significant \\
\hline
\end{tabular}

Table 4 Statistical parameters referring to the analytical models performances

\begin{tabular}{|c|c|c|c|c|c|c|c|c|c|}
\hline \multirow[t]{2}{*}{ Analytical model } & \multirow[t]{2}{*}{ Bias } & \multirow[t]{2}{*}{ RMSE } & \multirow[t]{2}{*}{ SI } & \multicolumn{2}{|c|}{$\begin{array}{l}\text { Pearson correla- } \\
\text { tion }\end{array}$} & \multicolumn{2}{|l|}{$t$ test } & \multicolumn{2}{|c|}{$\begin{array}{l}\text { Spearman's rank } \\
\text { correlation }\end{array}$} \\
\hline & & & & $r_{95 \%}$ & $R^{2}$ & $t_{95 \%}{ }^{\mathrm{a}}$ & Result & $r_{\mathrm{s}} 95 \%$ & $P$ value \\
\hline CERC [24] & 0.03 & 0.33 & 0.0010 & 0.71 & 0.50 & 2.25 & 1-hypothesis rejected & 0.81 & 0.0001 \\
\hline Kamphuis [25] & -0.35 & 1.46 & 0.0046 & 0.76 & 0.58 & 2.99 & 1-hypothesis rejected & 0.44 & 0.0762 \\
\hline Bayram et al. [26] & 0.09 & 1.08 & 0.0034 & 0.49 & 0.25 & 2.37 & 1-hypothesis rejected & 0.80 & 0.0002 \\
\hline Van Rijn [23] & -0.05 & 0.18 & 0.0006 & 0.93 & 0.86 & 1.40 & 0-hypothesis not rejected & 0.86 & 0 \\
\hline
\end{tabular}

${ }^{a}$ Hypothesis test based on Student's t-distribution, with 16 freedom degrees and a critical value $t_{\mathrm{cr}}=2.120$, for a significance level $a=0.05$. Null hypothesis $H_{0}-\mu_{\text {MODEL }}=\mu_{\text {in situi }}$ alternative hypothesis $H_{1} \_\mu_{\text {MODEL }} \neq \mu_{\text {in situ }}$

than by observations and filming in the beach field work as made by Perotto [27] and Fontoura et al. [2]. Moreover, the conversion of wave parameters was relevant for this study considering that longshore currents are mostly influenced by nearshore breaking waves. During wave propagation from deep waters to $15-\mathrm{m}$ and $18-\mathrm{m}$ isobaths, wave transformation processes start, and as they gradually approach shallower waters, $H_{\mathrm{S}}$ and $D_{\mathrm{P}}$ change their values as an adjustment caused by energy conservation through these processes (i.e. refraction, diffraction and shoaling). $D_{\mathrm{p}}$ is modified in a way the crests tend to become parallel to the bathymetric contours. Therefore, NE and SW waves gradually disappear, focusing their directions on $E$ and SE quadrants in the southern coast of Rio Grande do Sul [2], quadrants which are associated with the most energetic scenarios, and so the highest LST rates. The alterations occurred in $D_{\mathrm{p}}$ are mainly attributed to refraction, and the variations occurred in $H_{\mathrm{S}}$ represent, partially, the redistribution of the energy flux seeking its conservation.
Furthermore, wave celerity and length diminish progressively towards the coast at the same time wave height tends to increase (these values will keep changing until the wave breaks, dissipating its energy), and the period remains nearly constant [3].

\subsection{LST rates}

The predictability skill of each analytical model depends on the parameters involved in the equations for the calculation of LST rates. Accordingly, different analytical formulae resulted in distinct values for the same meteoceanographic conditions.

Van Rijn [23] was proven to be applicable in sandy and mixed beach systems, given its good performance among all the different beaches studied herein. Notwithstanding, the models elected as most adequate tend to underestimate the observed rates during high-energy scenarios, like the other two tested. The underrates can 
be partially attributed to the inaccuracy of the coefficients involved in the equations, as discussed by Van Rijn [23] through the suggestion of a new formula with calibrated factors, and also related to the lack of sampled data during high-energy events, since these values are usually not considered in model validation and calibration, and it is when the highest LST rates occur [2]. Moreover, wind influence is only considered in Van Rijn [23] and Bayram et al. [26] calculations through the LC velocity. Considering the wind's potential to alter longshore currents, and so the LST, as seen in the multilinear regressions (Table 3 ), the underrates associated with high-energy conditions may be attributed to the negligence of relevant wind components in the analytical models. This is exemplified by 07 August 2018 scenario, date in which the biggest LST value was observed, but none of the models were able to fully predict it, and the wind velocity was expressive (around $7 \mathrm{~m} \mathrm{~s}^{-1}$ with $8 \mathrm{~m} \mathrm{~s}^{-1}$ gusts). Bayram et al. [26] contemplate wind effects, but it does not consider beach slope and $D_{50}$ (sediment size is indirectly considered through $W_{\mathrm{s}}$ ). Given these two parameters are very relevant for LST, jointly with wave properties $[4,14,23]$, and considering that $W_{\mathrm{S}}$ does not change the net longshore transport, as computed by [14, 26], predictions presented many inaccuracies. In that way, further investigations are required to validate a model with a more accurate wind effect, and to calibrate the Van Rijn [23] equation, increasing, possibly, its accuracy.

The tendencies observed presented a positive proportionality between $H_{S}$, beach slope and LST rates, and a negative proportion with $D_{50}[4,14,23,26]$, likewise the trends occurring in the results herein. Albardão and Concheiros Sul scenarios exemplify the effect of $D_{50}$, in which the suspended load transport is diminished because grain size increases. $D_{50}, \tan \beta, H_{\mathrm{S}}$ and $D_{\mathrm{P}}$ at the breaker line are the key parameters for predicting LST rates according to [23]. Waves are also the most influent agent in the current study; however, the most significant regression responses are associated with $T_{\mathrm{p}}$ (influencing wave type and energy), instead of $D_{p}$ as postulated in [23], although wave propagation direction was still very significant in this research. This may be related to the importance of swell effect, computed indirectly through peak wave period, and highlighted by the good performance of Van Rijn [23].

Bergillos et al. [13] evaluated the performance of empirical equations (i.e. Inman and Bagnold [7], CERC [24], Kamphuis [25] and Van Rijn [23]) through RMSE and through a ratio between the predicted and the observed rates. Their results pointed that all four equations tend to overestimate LST rates when $D_{50}$ is based on the sandy fraction of bimodal beaches, but Van Rijn [23] is still the most accurate model overall. When gravel is considered, [23] efficiency is improved and the model presents the lowest RMSE associated, highlighting, once more, that grain size is a key parameter for estimating LST rates.

Concheiros Beach has a bimodal sediment distribution $\left(D_{50}=0.2102\right.$ and $D_{50}=0.707 \mathrm{~mm}$ according to [28]), and like Bergillos et al. [13], the most accurate LST rates were found in this study when the gravel fraction was under consideration. Therefore, the agreement with [13] results sustain, once again, Van Rijn [23] as the most adequate model for the southern coast of RS, since the best model elected by them is the same found herein, and they also looked for a model applicable in sandy, mixed and shingle beaches. The current study area is predominantly composed of fine sandy beaches, but the southernmost stretches are composed of coarse sand and biodetritic gravel (i.e. Sarita, Albardão, Concheiros). Thus, Van Rijn [23] applicability is proven to be efficient on coasts with a variable grain composition.

LST behavioural response will be different for each beach morphodynamic stage and meteoceanographic component in intensity, in agreement proportion, and in different time and space scales (may these components be related to wind, waves, tide, sedimentology, geomorphology and/or others). Furthermore, the contribution of each property able to influence the LST mechanism is not fully understood, and their weight factors still need to be investigated, specially when it concerns new tests with datasets around different world regions [12-14, 16, 20, 21, 52-55]. Therefrom, studies referring to each specific study area may be conducted, considering the main characteristics of the beach system under study, so the most applicable methodology can be chosen and the prediction of LST rates can be more accurate.

\section{Conclusions}

The observed LST rates demonstrated that this phenomenon varies as a function of daily meteoceanographic conditions, specially referring to wave and wind components. The predictability skill of each model is dependent on the parameters considered in its main equation, and the factors of influence each one has over the LST. Therefore, the results obtained through distinct analytical formulae were discrepant for the same beach under the same meteoceanographic scenario.

Wave parameters, median grain size and beach slope were proven to strongly influence longshore sediment transport, as found by previous studies, corresponding to the choice of best model overall. During high-energy scenarios, predictions were underestimated for all analytical models considered herein. Van Rijn [23] results were slightly closer to the observed rates, when compared to 
the others, and this may be attributed to its inclusion of swell factor and wind-induced longshore velocity, demonstrating the importance of wind in LST predictions.

Results herein can be compared with available literature in other regions around the world, but it is important to notice that LST behavioural response and model's effectiveness will be different for each specific study area, especially in what concerns the beach morphodynamic stage and proportionality feedback between longshore transport and system component. Hence, the method prediction accuracy depends greatly on the suitability of the dataset with respect to the analytical model being used.

Overall, this study demonstrates that every effort towards the assessment of LST is still needed since it has been studied for many decades by scientists from all around the world, and it is not fully comprehended yet, still presenting inaccuracies.

Acknowledgements This study had the support of Laboratório de Oceanografia Geológica-LOG_at Universidade Federal do Rio Grande-FURG. The authors also acknowledge Dr. José A. S. Fontoura for providing all the information regarding field surveys with streamer traps, besides the equipment itself, which were indispensable for obtaining the data used herein.

Author contributions All authors contributed to the study conception and design. Material preparation, data collection and analysis were performed by Gabrielle Pereira Quadrado and Elaine Siqueira Goulart. The first draft of the manuscript was written by Gabrielle Pereira Quadrado, and both authors commented on previous versions of the manuscript. All authors read and approved the final manuscript.

Availability of data and material Most of the data used herein were collected and analyzed by the authors (these are specified along the manuscript), although wave data were provided by the Sistema de Monitoramento da Costa Brasileira-SiMCosta, and some predictive scenarios were simulated using the datasets of Perotto [27] and Fontoura et al. [2].

Code availability Analytical models, statistical tests and graphs were computed through MATLAB. The map referring to the study area was produced in QGIS3.4.

\section{Compliance with ethical standards}

Conflicts of interest The authors declare that they have no conflict of interest.

\section{References}

1. Wright LD, Short AD (1984) Morphodynamic variability of surf zones and beaches: a synthesis. Mar Geol 56(1-4):93-118

2. Fontoura JAS, Almeida LE, Calliari LJ, Cavalcanti AM, Moller OJ, Romeu MAR, Christófaro BR (2013) Coastal hydrodynamics and longshore transport of sand on Cassino Beach and on Mar Grosso Beach, Southern Brazil. J Coast Res Coconut Creek 289:855-869
3. Komar PD (1998) Beach processes and sedimentation, 2nd edn. Prentice Hall, Upper Saddle River

4. Mil-Homens J, Ranasinghe R, van de Thiel Vries JSM, Stive MJF (2013) Re-evaluation and improvement of three commonly used bulk longshore sediment transport formulas. Coast Eng 75:29-39

5. Sedrati M, Anthony EJ (2007) Storm-generated morphological change and longshore sand transport in the intertidal zone of a multi-barred macrotidal beach. Mar Geol 244:201-229

6. Wyrtki VK (1953) The balance of littoral transport in the surf zone. Deutsche Hydrographische Zeitschrift 6(2):65-76

7. Inman DL, Bagnold RA (1963) Littoral processes. In: Hill MN (ed) The sea 3: the earth beneath the sea history. Interscience, New York, pp 529-533

8. Komar PD, Inman DL (1970) Longshore sand transport on beaches. J Geophys Res 75(3):5914-5927

9. Kraus NC (1987) Application of portable traps for obtaining point measurements of sediment transport rates in the surf zone. J Coast Res 3(2):139-152

10. Camenen B, Larroudé P (2003) Comparison of sediment transport formulae for the coastal environment. Coast Eng 48(2):111-132

11. Hanson H, Kraus NC (2011) Long-term evolution of a longterm evolution model. J Coast Res 59(Special Issue):118-129

12. Fernandéz SF, Baptista $P$, Martins VA, Silva PA, Abreu T, PaisBarbosa J, Bernardes C, Miranda P, Rocha MVL, Santos F, Bernabeu A, Rey D (2016) Longshore transport estimation on Ofir Beach in Northwest Portugal: sand-tracer. J Waterw Port Coast Ocean Eng 142(2):1-14

13. Bergillos RJ, Ortega-Sanchéz M, Masselink G, Losada MA (2016) Morpho-sedimentary dynamics of a microtidal mixed sand and gravel beach, Playa Granada, southern Spain. Mar Geol 379:28-38

14. Noujas V, Kankara RS, Rasheed K (2018) Estimation of longshore sediment transport rate for a typical pocket beach along west coast of India. Mar Geod 41(2):201-216

15. Khalfani D, Boutiba M (2019) Longshore sediment transport rate estimation near harbor under low and high wave-energy conditions: fluorescent tracers experiment. J Waterw Port Coast Ocean Eng 145(4):04019015

16. Bergillos RJ, Rodríguez-Delgado C, Ortega-Sánchez M (2017) Advances in management tools for modeling artificial nourishments in mixed beaches. J Mar Syst 172:1-13

17. Mason T, Voulgaris G, Simmonds DJ, Collins MB (1997) Hydrodynamics and sediment transport on composite (mixed sand/ shingle) and sand beaches: a comparison. In: Proceedings of the 3 rd coastal dynamics. ASCE, pp 48-57

18. Buscombe D, Masselink G (2006) Concepts in gravel beach dynamics. Earth Sci Rev 79:33-52

19. Masselink G, McCall RT, Poate T, Van Geer P (2014) Modelling storm response on gravel beaches using XBeach-G. In: Proceedings of the institution of civil engineers-maritime engineering. Thomas Telford Ltd., pp 173-191

20. Tomasicchio GR, D'Alessandro F, Barbaro G, Maiara G (2013) General longshore transport model. Coast Eng 71(1):28-36

21. Tomasicchio GR, D'Alessandro F, Barbaro G, Musci E, De Giosa TM (2015) Longshore transport at shingle beaches: an independent verification of the general model. Coast Eng 104:69-75

22. Van Rijn LC (2002) Longshore sand transport. In: 28th international conference on coastal engineering (ICCE) Cardiff, UK, pp 2439-2451

23. Van Rijn LC (2014) A simple general expression for longshore transport of sand, gravel and shingle. Coast Eng 90:23-33

24. U.S. Army Corps of Engineers (USACE) (1984) Shore protection manual. Coastal Engineering Research Center (CERC), US Army 
Corps of Engineers Research and Development Center, Coastal and Hydraulics Laboratory, v. 2, Vicksburg, Mississippi.

25. Kamphuis JW (1991) Alongshore sediment transport rate. J Waterw Port Coast Ocean Eng 117(6):624-640

26. Bayram A, Larson M, Hanson $H$ (2007) A new formula for the total longshore sediment transport rate. Coast Eng 54:700-710

27. Perotto H (2007) Influência do transporte sedimentar longitudinal nas variações da linha de costa no litoral sul do Rio Grande do Sul. Monograph, Federal University of Rio Grande - FURG.

28. Calliari LJ, Klein AHF, Barros FCR (1996) Beach differentiation along the Rio Grande do Sul coastline (Southern Brazil). Rev Chil de Hist Nat 69:485-493

29. Figueiredo SA, Calliari LJ (2006) Sedimentologia e suas Implicações na Morfodinâmica das Praias Adjacentes às Desembocaduras da Linha de Costa do Rio Grande do Sul. Gravel 4:73-87

30. Goulart ES (2014) Variabilidade morfodinâmica temporal e eventos de inundação em um sistema praial com múltiplos bancos. Thesis, Doctoral dissertation. Federal University of Rio Grande - FURG

31. Guedes RMC, Calliari LJ, Pereira PS (2009) Morfodinâmica da praia e zona de arrebentação do Cassino, RS através de técnicas de video imageamento e perfis de praia. Pesquisas em Geociências 36(2):165-180

32. Calliari LJ, Klein AHF (1993) Características Morfodinâmicas e Sedimentológicas das Praias Oceânicas Entre Rio Grande e Chuí, RS. Pesquisas em Geociências 20:48-56

33. Espírito Santo RM (2007) Variabilidade morfodinâmicas entre as regiões da Querência e do Navio Altair na Praia do Cassino, RS, Brasil. Dissertação (Mestrado em Oceanografia Química, Física e Geológica)—Universidade Federal do Rio Grande_FURG, Rio Grande.

34. Martins LR (1967) Aspectos deposicionais e texturais dos sedimentos praiais e eólicos da Planície Costeira do Rio Grande do Sul. Publicação Especial da Escola de Geologia, Universidade Federal do Rio Grande do Sul_UFRGS, Porto Alegre

35. Bessler KE, Rodrigues LC (2007) The polymorphs of calcium carbonate-an easy synthesis of aragonite. Química Nova 31(1):178-180

36. Tomazelli LJ, Villwock JA (1992) Algumas Considerações sobre o Ambiente Praial e a Deriva Litorânea de Sedimentos ao longo do Litoral Norte do Rio Grande do Sul, Brasil. Pesquisas em Geociências 19:1-26

37. Parise CK, Calliari LJ, Krusche N (2009) Extreme storm surges in the South of Brazil: atmospheric conditions and shore erosion. Braz J Oceanogr 57(3):175-188

38. Reboíta MS, Krusche N, Piccoli HC (2006) Climate variability in Rio Grande, RS, Brazil: a quantitative analysis of contributions due to atmospheric systems. Rev Bras Meteorol 21(2):256-270

39. Williams JJ, Esteves LS (2006) Predicting shoreline response to changes in longshore sediment transport for the Rio Grande do Sul coastline. Braz J Aquat Sci Technol 10(1):1-9

40. Esteves LS, Williams JJ, Dillenburg SR (2006) Seasonal and interanual influences of the patterns of shoreline changes in Rio Grande do Sul, Southern Brazil. J Coast Res 22(5):1076-1093

41. Albuquerque MG, Fontoura JAS, Calliari LJ, Serpa CG, Falcão TO (2008) Caracterização do fluxo sedimentar na zona de surfe de praias de micro e meso marés - aplicação a praia do Cassino (RS) e praia do Futuro (CE). In: Anais do III Seminário e Workshop em Engenharia Oceânica (SEMENGO'2008). Rio Grande, RS, Brasil: Universidade Federal do Rio Grande (FURG)

42. Wang P, Kraus NC, Davis RA Jr (1998) Total longshore sediment transport rate in the surf zone: field measurements and empirical predictions. J Coast Res 14(1):269-282

43. Holman RA, Stanley J (2007) The history and technical capabilities of Argus. Coast Eng 54:477-491

44. Guedes RMC (2008) Utilização de métodos diretos e videoimagens ARGUS na caracterização morfodinâmicas da zona de arrebentação da Praia do Cassino, RS. Dissertação (Mestrado em Oceanografia Física, Química e Geológica) - Universidade Federal do Rio Grande - FURG, Rio Grande

45. Ribeiro KG, Goulart ES (2017) Identificação manual e semiautomática da zona de arrebentação em video imagens. Anais do Congresso da ABEQUA 2017-Mudanças Climáticas no Passado e no Presente: conhecer para entender as consequências no future. Bertioga, p 3

46. Kamphuis JW, Readshaw JS (1978) A model study of alongshore sediment transport rate. In: Proceedings of 16th international conference on coastal engineering. ASCE Press, New York, pp 1656-1674

47. Bailard JA (1981) An energetics total load sediment transport model for a plane sloping beach. J Geophys Res 86(C11):10938

48. Leont'yev IO (1989) Dynamics of surf zone. Shirshov Institute of Oceanology USSR Science Academy, Moscow

49. Dell Valle R, Medina R, Losada MA (1993) Dependence of coefficient $\mathrm{K}$ on grain size. J Waterw Port Coast Ocean Eng 119:568-574

50. Dean RG, Dalrymple RA (2002) Coastal processes with engineering applications. Cambridge University Press, Cambridge

51. Quenouille MH (1949) Problems in plane sampling. Ann Math Stat 20(3):355-375

52. Jackson NL, Nordstrom KF, Farrel EJ (2017) Longshore sediment transport and foreshore change in the swash zone of an estuarine beach. Mar Geol 386:88-97

53. Sheela LN, Sundar V, Kurian NP (2015) Longshore sediment transport along the coast of Kerala in Southwest India. Procedia Eng 116:40-46

54. Sadeghifar T, Barati R (2018) Prediction of longshore sediment transport rate using soft computing techniques and comparison with semi-empirical formulas. In: International Energy and Environment. Chapter 8 Progress in River Engineering \& Hydraulic Structures, vol 2. pp 151-174

55. Moghaddam El, Hakimzadeh H (2019) Wave climate variability and longshore sediment transport evaluation along Ramin Harbor, Southeast Coast of Iran. Int J Coast Offshore Eng 2(3):53-62

56. Wentworth CK (1922) A scale of grade and class terms for clastic sediments. J Geol 30:377-392

Publisher's Note Springer Nature remains neutral with regard to jurisdictional claims in published maps and institutional affiliations. 